\title{
IMPACT OF SELECTED MECHANICAL PROPERTIES OF SWEETCORN SEED ON THE LEVEL OF CUTTING IT OFF FROM THE COB STEM
}

\author{
Mariusz Szymanek ${ }^{\mathrm{a}^{*}}$ Wojciech Tanaś ${ }^{\mathrm{b}}$ \\ a Department of Agricultural, Forest and Transport Machinery, University of Life Sciences in Lublin, \\ Poland, mariusz.szymanek@ up.lublin.pl ORCID 0000-0002-3337-0337 \\ b Department of Agricultural, Forest and Transport Machinery, University of Life Sciences in Lublin, \\ Poland, wojciech.tanas@up.lublin.pl ORCID 0000-0002-9544-8902 \\ "Corresponding author: e-mail: mariusz.szymanek@up.lublin.pl

\begin{tabular}{|c|c|}
\hline ARTICLE INFO & ABSTRACT \\
\hline $\begin{array}{l}\text { Article history: } \\
\text { Received: September } 2019 \\
\text { Received in the revised form: } \\
\text { October } 2019 \\
\text { Accepted: December } 2019\end{array}$ & \multirow{2}{*}{$\begin{array}{l}\text { Research results on the quality of work of a seed cutter for selected cul- } \\
\text { tivars of sweetcorn were presented. Measurements were carried out at } \\
\text { the rotational speed of a head of } 1600 \text { rot. } \min ^{-1} \text { and a linear velocity of } \\
\text { the cob conveyor of } 0.31 \mathrm{~m} \cdot \mathrm{s}^{-1} \text {. A statistically significant relation be- } \\
\text { tween the degree of cutting the seed mass and the selected mechanical } \\
\text { properties of grain were determined. Differences between cultivars at } \\
\text { the level of approximately } 43 \% \text { for the force of perforation of the peri- } \\
\text { carp } F_{p} \text {, }\end{array}$} \\
\hline $\begin{array}{l}\text { Key words: } \\
\text { sweetcorn, } \\
\text { performance, } \\
\text { force of perforation, } \\
\text { level of cutting }\end{array}$ & \\
\hline
\end{tabular}

\section{Introduction}

Sweetcorn is a plant, the sowing area of which, both for the demand of the so-called fresh market as well as for processing purposes in Poland and Europe increases systematically (Waligóra, 2005; Oktem et al., 2010). Interest in it results from both a high nutritive value of a seed and a new form of its obtaining (Turgut et al., 2005; Walkowiak, 2005; Bakry et al., 2015). The seed quality and physical properties of the corn seed depend on many factors including fertilization (Wójcik, 2005; Zaniewicz-Bajkowska et al., 2010), and seed moisture (Coskun et al., 2006; Karababa and Coskuber, 2007; Maoguo et al., 2015). A process of mechanical cutting of sweetcorn seeds from the cob stems for consumption (canning, freezing) in food processing plants takes place with traditional cutting devices. Obtaining edible sweetcorn seeds during cutting it off from cob stems ensures considerably a high performance at low expenditures of work at the expense of high losses of precious raw material (Brecht, 2004). In food processing from 1 kilo of cobs one obtains from 0.32 to 0.40 kilo of seed (Warzecha, 2005). The average amount of seed cut off from cobs is $35-55 \%$ (Feibert and Shock, 1996).

Mechanical influence of knives on the viscoelastic material that is cut off causes its relatively high quantitative and qualitative losses. The reasons for that can be found in biological 
material (an irregular shape of cobs, close adjustment of soft, moist, and immature seeds to each other and to cobs), its physical properties and properties of the seed cutter (exploitation and structural parameters). Modern technologies of harvesting and separating seeds from corn stems require knowledge on mechanical properties of cobs and corn seeds which have impact on optimization of these processes and limitation of seed losses.

In many machines used in the food processing, a mechanical impact is a basic function of working elements. Therefore, knowledge of material (raw material) properties on which selection of the nature and intensity of these impacts depends on (mechanical properties) (Ratajczak, 1994).

In cutting off sweetcorn seeds except for structure and mechanical properties influenced by the chemical composition (sugar content) and performed technological treatments (e.g. blanching), the moisture content is also significant (Wong et al. 1994; Özlem et al., 2014).

Having this in mind an attempt was made to determine the impact of the selected mechanical properties of sweetcorn seed on the level of cutting it off from the cob stem.

The aim of the paper was to find and determine the level of correlation between the selected physical properties of sweetcorn seeds and the level of cutting off the seed mass from the cob stem.

\section{Material and research methods}

Sweetcorn cobs Candle, Shaker and Powerhouse cultivars were the research material. Cobs with a prominent level of seeding, parallelism, cylindrical shape, and regular rows of seeds were selected for research after cleansing.

Cobs for research were manually collected in the dairy maturity stage and with the seed moisture within 76.4 to $77.8 \%$ in the first decade of September 2018 .

Basic research concerning measurements of mechanical properties of seeds and level of cutting the seed mass were preceded by determination of the characteristic of basic physical properties of cobs and seeds (table 1).

The mass of 1000 seeds was marked pursuant to standard PN-R-74017 while the seed moisture pursuant to PN-EN ISO 6540.

Research on mechanical properties of a seed were determined based on the penetration tests (Szymanek et al., 2004). These tests were carried out on a universal strength machine Instron 6022. For research, a steel penetrometer with a cylindrical endpoint with a diameter of $2 \mathrm{~mm}$ was used. The translocation speed of penetrometer was $50 \mathrm{~mm} \cdot \mathrm{min}^{-1}$ while its load was $100 \mathrm{~N}$. From the graph of relations of force-deformation, the average values of $\mathrm{F}$ force needed for penetration of the pericarp and corresponding deformation $\mathrm{L}$ were determined.

Resistance of pericarp to penetration was determined as a relation of the maximum force of penetration to the cross-section field of the penetrometer:

$$
R_{p}=\frac{F_{p}}{A_{o}}
$$

where:

$R_{p} \quad-$ resistance of the pericarp to MPa penetration,

$F_{p} \quad$ - force necessary to penetrate $\mathrm{N}$ pericarp,

$A_{o} \quad-$ cross-sectional area of penetrometer, $\mathrm{m}^{2}$ 
Impact of selected...

Table 1.

Characteristics of sweetcorn cobs

\begin{tabular}{|c|c|c|c|c|}
\hline Specification & & Candle & Shaker & Cob mass, $\mathrm{g}$ \\
\hline \multirow{2}{*}{ Cob mass, $\mathrm{g}$} & X́śr & 321.4 & 361.2 & 313.8 \\
\hline & $\mathrm{s}$ & 17.2 & 15.4 & 18.3 \\
\hline \multirow{2}{*}{ Cob length, mm } & $\mathrm{x}$ & 19.7 & 18.2 & 19.4 \\
\hline & $\mathrm{s}$ & 3.9 & 4.1 & 3.7 \\
\hline \multirow{2}{*}{ Cob diameter ${ }^{*}, \mathrm{~mm}$} & $\mathrm{x}$ & 49.2 & 47.4 & 51.1 \\
\hline & $\mathrm{s}$ & 0.9 & 1.2 & 1.1 \\
\hline \multirow{2}{*}{ Seed length, mm } & $\mathrm{X}_{\text {śr }}$ & 8.7 & 7.8 & 9.1 \\
\hline & $\mathrm{s}$ & 1.4 & 1.2 & 1.3 \\
\hline \multirow{2}{*}{ Number of seeds in row, pcs. } & $\mathrm{X}_{\text {śr }}$ & 36.4 & 40.8 & 40.1 \\
\hline & $\mathrm{s}$ & 5.2 & 4.1 & 5.3 \\
\hline \multirow{2}{*}{ Number of seed rows, pcs. } & $\mathrm{x}$ & 14.2 & 15.7 & 17.1 \\
\hline & $\mathrm{s}$ & 2.2 & 3.3 & 3.2 \\
\hline \multirow{2}{*}{ Mass of 1000 seeds, g } & $\mathrm{x}$ & 301.1 & 285.5 & 240.6 \\
\hline & $\mathrm{s}$ & 17.4 & 14.1 & 12.4 \\
\hline \multirow{2}{*}{ Seed moisture, $\%$} & $\mathrm{x}$ & 77.8 & 75.2 & 76.4 \\
\hline & $\mathrm{s}$ & 2.9 & 2.7 & 2.6 \\
\hline \multirow{2}{*}{ Biological performance of seeds, $\%$} & $\mathrm{x}$ & 72.6 & 70.3 & 69.8 \\
\hline & $\mathrm{s}$ & 1.8 & 2.1 & 1.2 \\
\hline
\end{tabular}

$\mathrm{x}_{\mathrm{sr}}-$ arithmetic mean; $\mathrm{s}-$ standard deviation, $*$ - measured in the central part of a cob

Schematic representation of the research stand and the method of measurement was presented in figure 1.

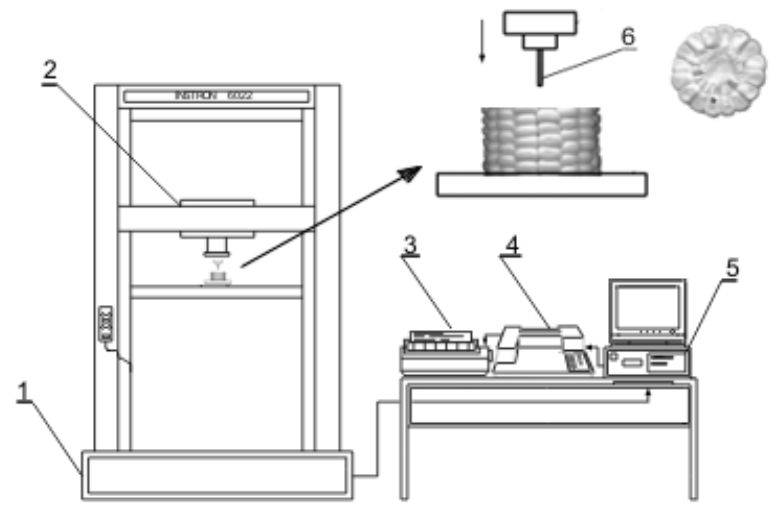

Figure 1. Diagram of the test rigs: 1 - strength machine Instron 6022, 2 -measurement head 3 - printer, 4 -plotter, 5 - computer, 6 -penetrometer 
Since seedlings in the central part of a cob have a more regular shape and comparable size, therefore they were the object of the research. A seed from the furthest parts of a cob whose participation in the entire cob is small, was not taken into consideration. Measurements were carried out for each variety on the test consisting of 60 seeds from 15 cobs.

Cutting of the seed from cob stems was carried out on the Corn Cutter SC -120 cutting unit by FMC Food Tech for the standard rotational speed of the knife head $1600 \mathrm{rot} \cdot \mathrm{min}^{-1}$ and the linear velocity of the cob conveyor $0.31 \mathrm{~m} \cdot \mathrm{s}^{-1}$. Measurement was carried out on the sample consisting in 300 cobs.

The level of cutting of the seed mass $\left(\mathrm{S}_{\mathrm{o} d}\right)$ was determined in two stages. In the first stage the participation of the mass of the cut off seed from the cob stem $\left(M_{o d}\right)$ was calculated according to the formula:

$$
M_{o d}=\frac{\left(m_{k}-m_{r}\right)}{m_{k}} \cdot 100(\%)
$$

where:

$m_{k} \quad$ - cob mass before the cutting process $(\mathrm{g})$,

$m_{r} \quad-$ stem mass (after cutting off the seed $(\mathrm{g})$,

And in the other stage the size was referred from the equation (2) to the biological performance of the seed $\left(\mathrm{W}_{b}\right)$ :

$$
S_{o d}=\frac{M_{o d}}{W_{b}} \cdot 100(\%)
$$

Biological performance of a seed $\left(\mathrm{W}_{b}\right)$ was determined pursuant to the following formula:

$$
W_{b}=\frac{m_{k}-m_{z}}{m_{k}} \cdot 100(\%)
$$

where:

$m_{z} \quad-$ seed mass $(\mathrm{g})$.

Biological performance of a seed for each cultivar was determined based on 30 cobs. A manually husked seed as well as stems were weighed on the laboratory scale WPE 2000p with precision of $0.1 \mathrm{~g}$.

Such a course of calculations resulted from difficulties of collection of all cut off seeds (which were partially scattered on the parts of the machine) and on account of the losses of juices and solid fractions as well as from difficulties of determination which part of seed mass remained on the stem.

One-way analysis of variance was used for statistical preparation of the research results. Significance of differences between the averages that characterize the investigated factors was estimated with the use of Tukey's confidence interval at the level of significance of $\alpha=0.05$. 
Impact of selected...

\section{Research results and their analysis}

One-way analyses of variance that were carried out for the force of penetration $\mathrm{F}_{\mathrm{p}}$, stress $\mathrm{Rp}$, deformation $\mathrm{L}$ and the degree of cutting seed $\mathrm{S}_{\mathrm{od}}$ showed statistically significant variability between the investigated cultivars (table 2). The qualitative conclusion made based on the basic Tukey's confidence interval proved for all investigated values (fig. 2, 3, 4 and 5) occurrence of significant differences between cultivars.

Table 2.

Results of the analysis of variance for investigated values

\begin{tabular}{lccccc}
\hline Specification & $\begin{array}{c}\text { Sum } \\
\text { of squares }\end{array}$ & $\begin{array}{c}\text { Average square } \\
\text { of deviations }\end{array}$ & $\begin{array}{c}\text { Average square } \\
\text { of deviations } \\
\text { of the rest }\end{array}$ & F test & $\begin{array}{c}\text { Level } \\
\text { of significance }\end{array}$ \\
\hline $\mathrm{F}_{\mathrm{p}}(\mathrm{N})$ & 792,11 & 1368,11 & 32,57 & 24,32 & 0,0000 \\
\hline $\mathrm{R}_{\mathrm{p}}(\mathrm{MPa})$ & 80,34 & 138,76 & 3,30 & 24,32 & 0,0000 \\
\hline $\mathrm{L}(\mathrm{mm})$ & 16,28 & 13,56 & 0,32 & 50,43 & 0,0000 \\
\hline $\mathrm{S}_{\mathrm{od}}(\%)$ & 445,20 & 423,82 & 10,1 & 44,12 & 0,0000 \\
\hline
\end{tabular}

Penetration force $F_{p}$ of the fruit seed coat was changing within the interval from ca. $21 \mathrm{~N}$ (Powerhouse) to ca. $36 \mathrm{~N}$ (Shaker). Statistically significant difference was reported. It corresponded to the difference of ca. $42 \%$. On the other hand, between Candle a Powerhouse was ca. $27 \%$ and Candle and Shaker ca. 19\% (Fig. 2). The average values of R stresses presented in figure 3 showed differences between Candle and Shaker cultivar of ca. 19\% Candle and Powerhouse ca. 27\% and Shaker and Powerhouse ca. 40\%. For similar relations between cultivars differences in the average values of deformation $\mathrm{L}$ were respectively ca. 22; 11 and $31 \%$ (Fig. 4) and in average values of the level of cutting seed mass $\mathrm{S}_{\text {od }}$ ca. 5; 9 and $14 \%$ (Fig. 5).

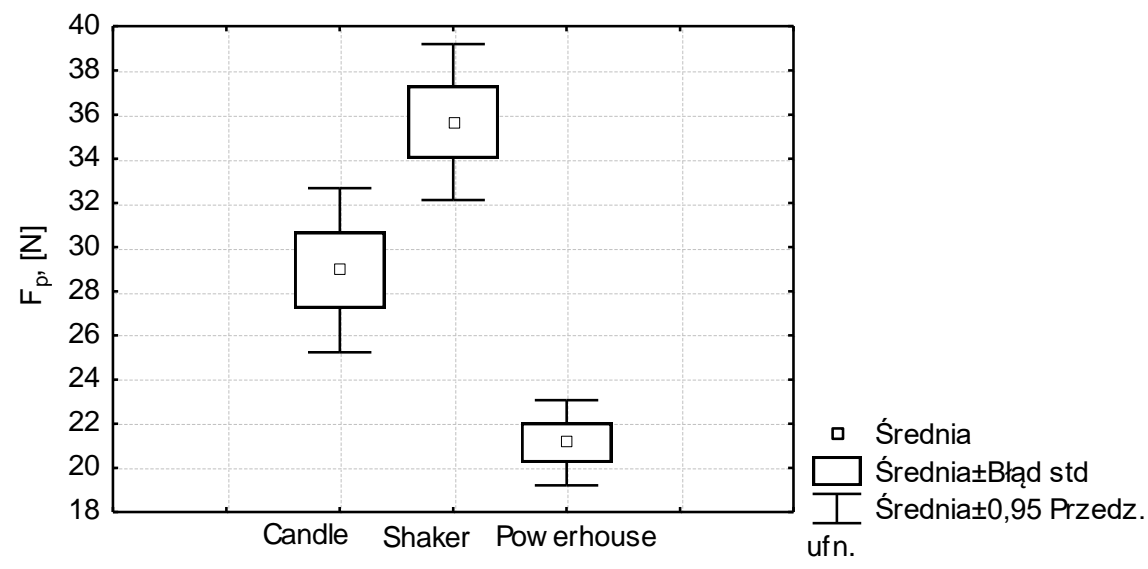

Figure 2. Results of penetration test for $F_{p}(N)$ 


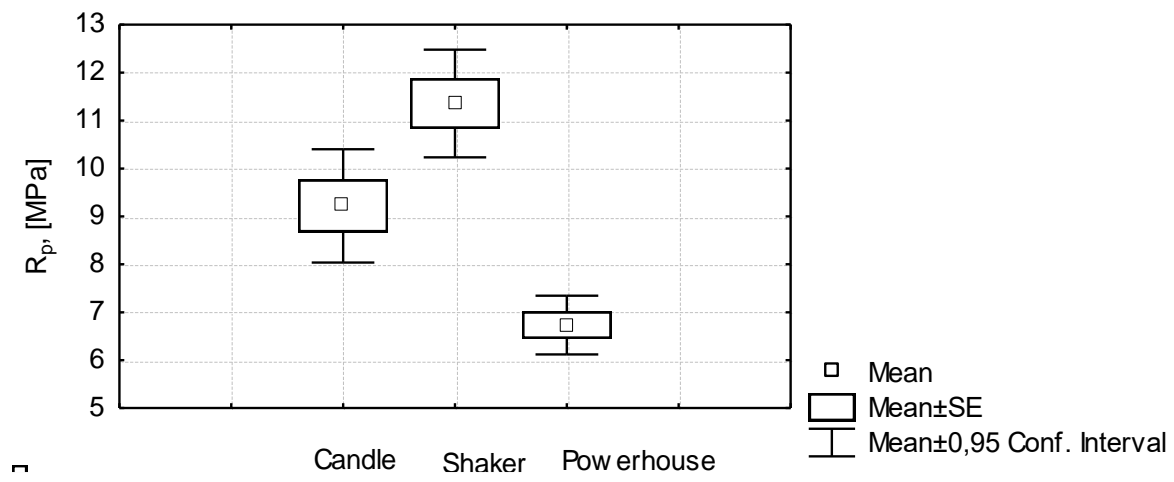

Figure 3. Results of penetration test for $R_{p}(M P a)$

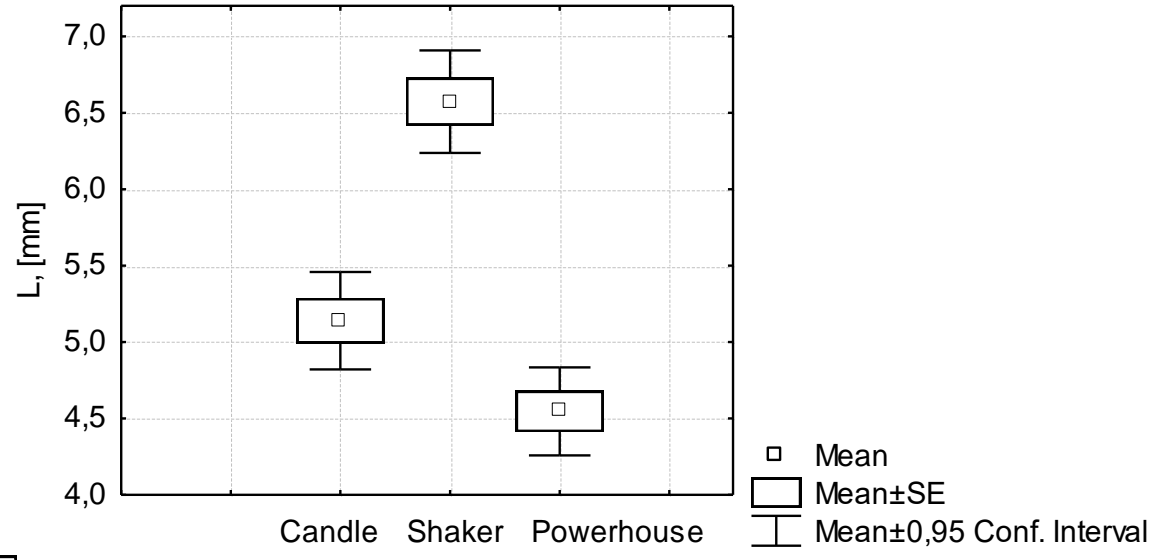

Figure 4. Results of penetration test for $L(\mathrm{~mm})$ 
Impact of selected...

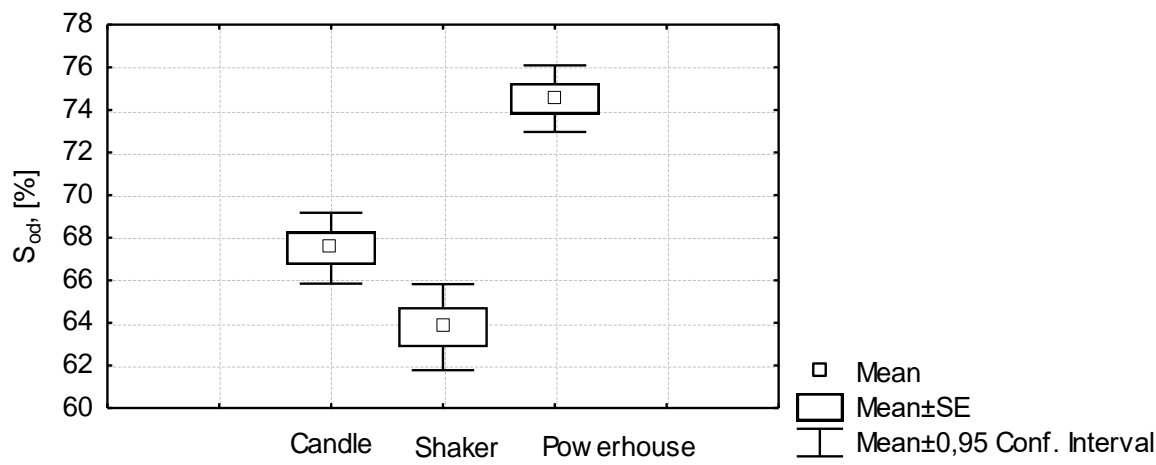

Figure 5. Average values $S_{\text {od }}(\%)$ for investigated cultivars

Table 3 presents results of the statistical analysis which determines the level of correlation between mechanical properties of a seed and the level of cutting off the cob stems for particular cultivars.

Table 3.

Set of values of correlation coefficients between the investigated mechanical properties and the degree of cutting of the seed mass

\begin{tabular}{lccc}
\hline \multirow{2}{*}{ Size } & \multicolumn{1}{c}{$\mathrm{S}_{\text {od }}$} \\
\cline { 2 - 4 } & $\begin{array}{c}\text { Coefficient of } \\
\text { correlation }\end{array}$ & $\mathrm{P} /|\mathrm{t}|>\mathrm{t}_{\mathrm{o}}$ & Significance \\
\hline $\mathrm{F}_{\mathrm{p}}$ & -0.75 & 0.0032 & $\mathrm{x}$ \\
$\mathrm{R}_{\mathrm{p}}$ & -0.71 & 0.0045 & $\mathrm{X}$ \\
$\mathrm{L}$ & -0.76 & 0.0024 & $\mathrm{x}$ \\
\hline $\mathrm{F}_{\mathrm{p}}$ & & Cultivar-Shaker & - \\
$\mathrm{R}_{\mathrm{p}}$ & -0.51 & 0.4501 & - \\
$\mathrm{L}$ & -0.57 & 0.3247 & - \\
\hline & -0.52 & 0.2743 & $\mathrm{x}$ \\
\hline $\mathrm{F}_{\mathrm{p}}$ & & Cultivar-Powerhouse & $\mathrm{x}$ \\
$\mathrm{R}_{\mathrm{p}}$ & -0.86 & 0.0024 & $\mathrm{x}$ \\
$\mathrm{L}$ & -0.82 & 0.0074 & \\
\hline $\mathrm{x}-$ significance;,$-”$ no significance & -0.87 & 0.0012 & \\
\end{tabular}

The presented analysis shows that the correlation coefficients assume absolute values within 0.51 to 0.87 . The highest values of correlation coefficients were obtained for Powerhouse culitvar and the lowest for Shaker cultivar. Mechanical properties of a seed of 
sweetcorn cob Shaker cultivar did not show any significant correlation with the level of cutting off the seed from the cob stem. While Candle and Powerhouse cultivar showed statistical significance and existence of correlation for all determined values.

\section{Conclusions}

1. The investigated cultivars are statistically significantly varied on account of the penetration force $F_{p}, R_{p}$ strength, deformation $L$ and level of cutting of seed $S_{\text {od. }}$.

2. Differences between the cultivars at the level of $42 \%$ for the penetration force $\mathrm{F}_{\mathrm{p}}$, ca. $27 \%$ for strength $R_{p}$, ca. $31 \%$ for deformation $L$ and ca. $14 \%$ for the cutting level of seed $S_{\text {od }}$ were observed.

3. All obtained coefficients of correlation are negative which shows that $S_{\text {od }}$ raises along with the decrease of value $F_{p}, R_{p}$ and $L$. This relation may be justified with a smaller plastic deformation of a seed and thus its smaller deformation during cutting. Cutting of the bent seed causes a shallower cut on the opposite side to the leading edge of the knife and thus the loss of a part of the plant material.

\section{References}

Brecht, J.K. (2004). "Sweetcorn. Postharvest quality maintenance guidelines”, in The Commercial Storage of Fruits K. Gross, C.-Y. Wang, and M. Saltveit (eds.)., Vegetables, and Florist \& Nursery Crops, 3rd ed. Agr. Hndbk. No. 66. U.S. Dept. Agr., Agr. Res. Serv., Washington, D.C.

Bakry, M.O., El-Shorbagy, T., EL-Desuki, M., El-Behairy, U.A., Ibrahim, H.A. (2015). Effect of some post-harvest treatments on sweet corn (Zea mays Var. Rugosa) quality during storage. Middle East Journal of Agriculture Research, 4(4), 925-931.

Coskun, M.B., Yalcin, I., Ozarslan, C. (2006). Physical properties of sweet corn seed (Zea mays saccharata Sturt.). Journal of Food Engineering, 74, 523-527.

Feibert, E., Shock, F. (1996). Supersweet corn and sweet corn variety evaluations. Malheur Experiment Station, Oregon State University Ontario, Oregon.

Karababa, E., Coskuner, Y. (2007). Moisture dependent physical properties of dry sweet corn kernels. International Journal of Food Properties, 10, 549-560.

Maoguo, X., Daolin, Z., Chunning, L. (2015). Analysis of Influence Factor on Corn Threshing Performance. Journal of Agricultural Mechanization Research. 1, 188-191.

Oktem, A., Oktem, A.G., Emeklier, H.Y. (2010). Effect of Nitrogen on Yield and Some Quality Parameters of Sweet Corn. Communications in Soil Science and Plant Analysis, 41(7), 832-847.

Özlem, A., Kinaci, G., Kinaci, E., Basciftci, Z. B., Sonmez, K., Evrenosoglu, Y.,Kutlu, I. (2014). Kernel quality of some sweet corn varieties in relation to processing. Notulae Botanicae Horti Agrobotanici Cluj-Napoca, 42(2), 414.

PN-R-74017: 1968. Ziarno zbóż i nasiona strączkowe jadalne - Oznaczanie masy 1000 ziarn.

PN-EN ISO 6540:2010. Oznaczanie wilgotności (rozdrobnionego i całego ziarna).

Ratajczak, W. (1994). Badania wytrzymatości na ściskanie owoców i warzyw. VI Sympozjum im. Prof. Cz. Kanafojskiego, Problemy budowy oraz eksploatacji maszyn I urządzeń rolniczych, Tom II, 2021.

Szymanek, M., Niedziółka, I., Dobrzański, B. jr. (2004). Właściwości fizyczne ziarna kukurydzy cukrowej w aspekcie jego mechanicznego odcinania. Rozprawy i monografie, 107(4), ISSN 1234-4125.,

Turgut, I., Bilgili, U., Duman, A., Acikgoz, E. (2005). Effect of green manuring on the yield of sweet corn. Agronomy for Sustainable Development, 25(4), 433-438. 
Impact of selected...

Waligóra, H. (2005). Kukurydza jadalna - znaczenie gospodarcze i rola w żywieniu człowieka. Kukurydza, 1(25), 75-78.

Walkowiak, A. (2005). Odmiany kukurydzy cukrowej. Warzywa, 4, 46-48.

Warzecha, R. (2005). Kukurydza cukrowa. Kukurydza roślina przyszłości. Poradnik dla producentów, wyd. III, Agroserwis, Warszawa, 33-36.

Wong, A.D., Juvik, J.A., Breeden, D.C, Swiader, J.M. (1994). Shrunken2 sweet corn yield and the chemical components of quality. Journal of American Society Horticultural Science, 119(4), $747-$ 755.

Wójcik, K. (2005). Wygrywa z groszkiem. Warzywa, 4, 30-32.

Zaniewicz-Bajkowska, A., Rosa, R., Kosterna, E., Franczuk, J., Buraczyńska, D. (2010). The effect of sunflower (Helianthus annuus L.) catch crop on content of selected components of nutritive value of sweet corn (Zea mays L. var. saccharata (Sturtev.) L.H. Bailey), Hortorum Cultus - Acta Scientiarum Polonorum, 9(4), 53-62.

\section{WPLYW WYBRANYCH WLAŚCIWOŚCI MECHANICZNYCH ZIARNA KUKURYDZY CUKROWEJ NA STOPIEŃ JEGO ODCIECCIA OD RDZENI KOLB}

Streszczenie. Przedstawiono wyniki badań jakości pracy obcinarki ziarna dla wybranych odmian kukurydzy cukrowej. Pomiary przeprowadzono przy prędkości obrotowej głowicy wynoszącej 1600 obr $\cdot \min ^{-1}$ i prędkości liniowej podajnika kolb $-0,31 \mathrm{~m} \cdot \mathrm{s}^{-1}$. Stwierdzono istotny statystyczny wpływ między stopniem odcięcia masy ziarna, a wybranymi właściwościami mechanicznymi ziarna. Zaobserwowano różnice pomiędzy odmianami na poziomie około $42 \%$ dla siły przebicia okrywy owocowonasiennej $\mathrm{F}_{\mathrm{p}}$, około $27 \%$ dla odporności na przebicie $\mathrm{R}_{\mathrm{p}}$, około $31 \%$ dla deformacji $\mathrm{L}$ i około $14 \%$ dla stopnia odcięcia ziarna $\mathrm{S}_{\text {od. }}$

Słowa kluczowe: kukurydza cukrowa, odmiany, kolby, ziarno, jakość odcinania 